\title{
Should patients with recent onset rheumatoid arthritis be offered genetic screening?
}

\author{
Deborah P M Symmons, William E R Ollier, Paul Brennan, Alan J Silman
}

Advances in molecular based technology and their application to the study of disease aetiology and pathology are having a significant and increasing impact on the practice of clinical medicine. This methodology can be applied not only to single gene disorders such as cystic fibrosis, but also to complex polygenic disorders such as ischaemic heart disease, certain cancers, and rheumatoid arthritis (RA). Some of the genetic factors identified may prove useful in screening for disease risk or indicating prognosis.

A recent Government document ${ }^{1}$ summarised how the application of genetics may be increasingly useful in medicine, and suggested that it may soon be appropriate to screen patients with early rheumatoid arthritis (RA) for HLA genotypes associated with a poor prognosis in order to guide treatment decisions. A similar recommendation was made in a recent paper by Emery and Salmon. ${ }^{2}$ Here, we review the evidence that has led to this suggestion and discuss the factors that need to be considered before genetic screening of patients with recent onset RA could be recommended as a routine procedure.

\section{Background}

To date, the strongest genetic association identified for RA is with the HLA complex. Since Statsny's original observation in 1978 that $R A$ is associated with HLA-DR4, ${ }^{3}$ many confirmatory studies have been published. It gradually became clear that different HLA-DR specificities were associated with $R A$ in different ethnic groups. ${ }^{4}$ The application of DNA sequencing and molecular based typing to detect HLA-DRB1 alleles showed that those associated with RA (HLA-DRB1*0101, ${ }^{\star} 0102,{ }^{\star} 0401,{ }^{\star} 0404,{ }^{\star} 0405,{ }^{\star} 0408,{ }^{\star} 1001$, and $\star 1402$ ) shared a consensus amino acid sequence (QKRAA or QRRAA) at positions 70-74 of the third hypervariable region of the HLA-DRB1 chain-a position that influences its interaction with the $T$ cell receptor. These studies led to the so called 'shared epitope' hypothesis, which unifies the various genetic associations in different populations. ${ }^{5}$ Using molecular techniques, it is now possible confidently to infer HLA-DRB1 genotypes (including whether individuals are homozygous) and to detect alleles carrying the shared epitope in a relatively simple, rapid, and inexpensive way.

\section{Susceptibility versus severity}

Considerable debate has centred around whether genes bearing the shared epitope are associated with susceptibility to the development of $R A$, or with a worse prognosis amongst RA sufferers. This distinction was initially suggested by a cross-sectional population based study of prevalent RA cases in the Netherlands, which found no association between HLA-DR4 and RA, but did find an association with radiological erosions. ${ }^{6}$ Similarly, a recent study of incident cases of RA seen in general practice in Norfolk (the Norfolk Arthritis Register) ${ }^{7}$ found only a weak association with HLA-DR4. In contrast, most hospital clinic series of RA patients demonstrate a strong association with HLA$\mathrm{DR} 4^{8}$ or the shared epitope, and this is more pronounced in patients with one of the most severe variants of RA, Felty's syndrome. ${ }^{9}$ Other studies have suggested that having a 'double dose' of the shared epitope, in particular HLA-DRB1*0401 and HLA$\mathrm{DRB} 1{ }^{\star} 0404$ combinations may also confer a worse prognosis. Weyand et al ${ }^{10}$ found that HLA-DRB $1{ }^{\star} 0401 /{ }^{\star} 0401$ homozygotes had the greatest risk of major organ involvement and 'compound heterozygotes' (HLA$\left.\mathrm{DRB} 1{ }^{\star} 0401 /{ }^{\star} 0404\right)$ the greatest risk for nodular RA. Two studies in the United Kingdom have also suggested that the greatest risk for severe RA is associated with the HLADRB $1^{\star} 0401 /{ }^{\star} 0404$ genotype. ${ }^{11} 12$ Both these genotypes (HLA-DRB $1{ }^{\star} 0401 /{ }^{\star} 0401$ and HLA-DRB $\left.1{ }^{\star} 0401 /{ }^{\star} 0404\right)$ are, however, relatively rare in the UK population. Tables 1 and 2 , respectively, summarise published data on the prevalence of RA associated genotypes in various populations, and on the frequency of erosions in RA patients with particular genotypes. In summary, these tables show that almost all patients with established RA possess the shared epitope. However, in early disease the frequency of the shared epitope is not increased significantly. Patients who are homozygous for the shared epitope, in particular if they have the HLA-DRB $1^{\star} 0401 /$ ${ }^{\star} 0401$ or HLA-DRB $1{ }^{\star} 0401 /{ }^{\star} 0404$ genotype, are at the greatest risk of developing radiological erosions. However, collectively these patients account for a very small proportion of those whose disease is erosive. Thus most patients ( $74 \%$ ) who have erosive disease are not homozygous for the shared epitope.

Oxford Road,

United Kingdom.

Accepted for publication 20 February 1996 
Table 1 Prevalence (as reported by various sources) of certain genotypes in control subjects and groups of patients with rheumatoid arthritis $(R A)$

\begin{tabular}{|c|c|c|c|c|c|}
\hline & \multirow{2}{*}{$\begin{array}{l}\text { Normal } \\
\text { white } \\
\text { population } \\
(\%)\end{array}$} & \multirow{2}{*}{$\begin{array}{l}\text { Community based } \\
\text { Early } R A \\
(\%)\end{array}$} & \multicolumn{2}{|c|}{ Hospital based } & \multirow{2}{*}{$\begin{array}{l}\text { Erosive } R A \\
\text { (\%) }\end{array}$} \\
\hline & & & $\begin{array}{l}\text { Early } R A \\
(\%)\end{array}$ & $\begin{array}{l}\text { Established } R A \\
\text { (\%) }\end{array}$ & \\
\hline SE- & $\begin{array}{l}48^{11} \\
55^{13}\end{array}$ & $\begin{array}{l}36^{15} \\
52^{\star}\end{array}$ & $36^{13}$ & $13^{11}$ & $\begin{array}{l}26^{13} \\
44^{\star}\end{array}$ \\
\hline $\mathrm{SE}+$ & $\begin{array}{l}45^{13} \\
52^{11}\end{array}$ & $\begin{array}{l}48^{\star} \\
64^{15}\end{array}$ & $64^{13}$ & $87^{11}$ & $\begin{array}{l}56^{\star} \\
74^{13}\end{array}$ \\
\hline HLA-DR4 & $31+$ & $42^{7}$ & $55^{16}$ & $\begin{array}{l}66^{4} \\
74^{8}\end{array}$ & $\begin{array}{l}44^{\star} \\
58^{16}\end{array}$ \\
\hline $\mathrm{SE}+/ \mathrm{SE}-$ & $35 t$ & $28^{\star}$ & - & - & $32^{\star}$ \\
\hline $\mathrm{SE}+/ \mathrm{SE}+$ & $9+$ & $\begin{array}{l}19^{\star} \\
23^{15}\end{array}$ & $23^{13}$ & $21^{14}$ & $\begin{array}{l}24^{\star} \\
26^{13} \\
46^{10}\end{array}$ \\
\hline $\begin{array}{l}\text { HLA-DRB1 } \\
{ }^{*} 0401 /{ }^{\star} 0401\end{array}$ & $\begin{array}{l}1 \cdot 3^{11} \\
1 \cdot 4^{13}\end{array}$ & $3^{\star}$ & $6^{13}$ & $5^{11}$ & $\begin{array}{r}3^{\star} \\
11^{10}\end{array}$ \\
\hline $\begin{array}{l}\text { HLA-DRB1 } \\
\star_{0401 / \star 0404}\end{array}$ & $1 \cdot 1^{11} 13$ & $5^{\star}$ & $9^{13}$ & $14^{11}$ & $\begin{array}{r}9^{\star} \\
12^{13} \\
14^{10}\end{array}$ \\
\hline
\end{tabular}

ॠUnpublished data from the Norfolk Arthritis Register: ${ }^{17}$ patients with disease duration less than two years.

UUnublished data from the Arthritis Research Council Epidemiology Research Unit.

${ }^{10}$ All patients in this study were seropositive, with disease duration more than three years. SE $=$ Shared epitope. treatment of RA will prevent the subsequent development of extra-articular disease.

The two principal outcome measures in RA are the development of radiological erosions and the development of functional disability. Whilst there is a degree of overlap between these two measures, it is by no means complete. The genetic associations of 'disabling' RA are much weaker than those for 'erosive' RA. ${ }^{21-23}$ Thus, while patients who are shared epitope positive have about double the risk of developing erosions compared with those who are shared epitope negative, the risk of being functionally disabled at one year is the same in the two groups (Norfolk Arthritis Register data). It is therefore important that treatment decisions in RA should not centre solely on the aim of preventing erosions. Patients with no erosions may experience significant pain and disability, and they too require appropriate treatment.

\section{Screening issues}

Before a screening test is introduced, certain criteria require consideration. ${ }^{24}$ These criteria were developed for use when the introduction of population screening for disease (for example screening for hypertension) may be considered, but they can be applied equally well to the introduction of a screening test in early disease to predict future outcome. They are examined here in the context of genetic screening of patients with early RA in order to predict the development of erosions:

(1) The population being screened should be at relatively high risk of developing the disease.

Patients with early $R A$ are at high risk (1 in 3) of developing erosions, so this criterion is satisfied.

(2) The undiagnosed disease should be of concern to the community being screened.

Whilst $R A$ patients are often not aware of the significance of erosions, their physicians are aware. Patient education can ensure that this criterion is met.

(3) The undiagnosed disease (erosions) should be more amenable to treatment at an early stage than it would be later.

As outlined above, this point has not been proven in the patients who screen positive.

(4) Individuals for whom the screening test is positive should be assured follow up evaluation.

Genetic screening in $R A$ patients should only be offered and interpreted by physicians in a position to provide expert long term management.

(5) The test should be highly sensitive and specific.

Table 3 shows the sensitivity and specificity of the different genotypes. None satisfies the requirement to be both sensitive and specific (as shown in the receiver operator characteristic curves (figure)). The most appropriate test would be for the shared epitope.

(6) The test should be applicable and acceptable to a large number of individuals.

Genetic screening would be performed using blood or mouth wash samples, which is generally acceptable. 
Table 3 Sensitivity and specificity of HLA genotype in predicting erosions in community and hospital based populations of patients with rheumatoid arthritis $(R A)$

\begin{tabular}{|c|c|c|c|c|}
\hline & \multicolumn{2}{|c|}{ Community based RA (Norfolk) } & \multicolumn{2}{|c|}{ Hospital based $R A$ (Birmingham) } \\
\hline & Sensitivity & Specificity & Sensitivity & Specificity \\
\hline $\begin{array}{l}\text { SE+ } \\
\text { HLA-DR4 } \\
\text { SE+/SE+ } \\
\text { HLA-DRB1 }\end{array}$ & $\begin{array}{l}56 \\
44 \\
21\end{array}$ & $\begin{array}{l}60 \\
76 \\
87\end{array}$ & $\begin{array}{l}74^{13} \\
72^{25} \\
26^{13}\end{array}$ & $\begin{array}{l}61^{13} \\
58^{25} \\
88^{13}\end{array}$ \\
\hline $\begin{array}{l}{ }^{\star} 0401 /{ }^{\star} 0401 \\
\text { HLA-DRB }\end{array}$ & 3 & 97 & - & - \\
\hline$\star^{\star} 0401 /{ }^{\star} 0404$ & 9 & 99 & $12^{13}$ & $97^{13}$ \\
\hline
\end{tabular}

SE $=$ Shared epitope. therapeutic benefit of early intervention require evaluation.

\section{Discussion}

When considering introducing a screening test, it is important to consider the implications both of a positive and of a negative test. Most patients with RA are shared epitope positive. However, given that a person has developed $\mathrm{RA}$, the finding of a negative shared epitope test is not reassuring: $19-30 \%$ of RA patients who are shared epitope negative develop erosions. There is some evidence from Sweden that in patients who are shared epitope negative their disease may become erosive later (after two years). ${ }^{23}$ Thus one could not recommend withholding antierosive treatment in this group. Those at greatest risk of eroding have the HLA-DRB1*0401/^0404 genotype. It could be argued that if these patients were identified early they could be targeted for the most aggressive treatment. However, it is possible that this small group of patients are just the ones who do not respond to treatment. What of a negative test for HLA-DRB $1^{\star} 0401 /$ $\star 0404$ ? The great majority of patients whose disease becomes erosive do not possess this genotype. They may be the ones who do respond to treatment and whose disease course can be altered. So, for the time being, genetic screening in RA should remain a research tool. We need to set up well designed clinical outcome studies of RA patients stratified by HLA-DRB1 genotypes and given a range of treatments.

We still have much to learn about the significance of the presence and absence of RA associated genotypes in the prognosis and response to treatment of RA patients.

1 NHS Central Research and Development Committee on the new genetics. The Genetics of Common Diseases-2nd the new genetics. The Genetics of Common Diseases-2nd

Report. London: HMSO, 1995. (Department of Health.) for remission? Ann Rheum Dis 1995; 54: 944-7.

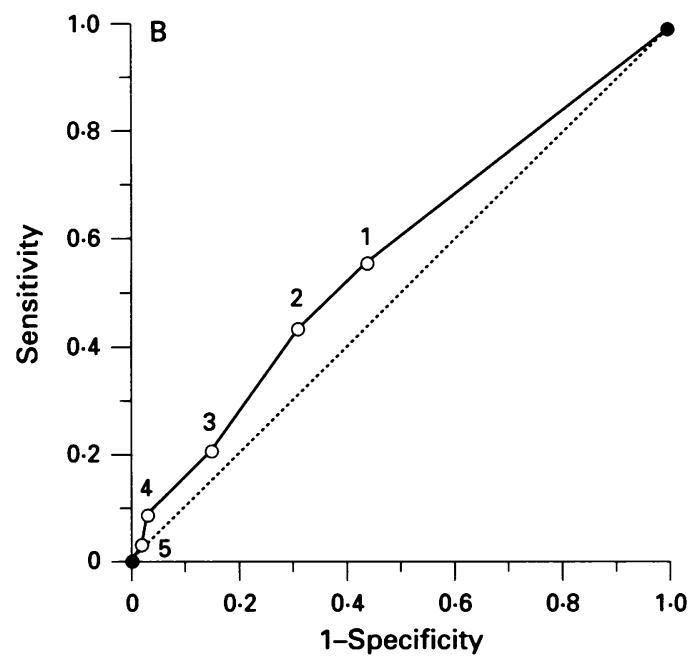

Receiver operator characteristic (ROC) curves for predicting erosions-A: using 120 hospital based patients with $R A$ from Birmingham; B: using 95 community based patients with $R A$ from Norfolk. ROC curves plot sensitivity over (1 - specificity). Tests with a high sensitivity and high specificity deviate maximally from the diagonal line and have a large area under the curve. Poorly discriminating tests lie on or near the diagonal line, which represents what one would expect by chance. 1 = Shared epitope positive; one would expect by chance. $1=$ Shared epitope positive; $D R B 1{ }^{\star} 0401{ }^{\star} 0404 ; 5=H L A-D R B 1^{*} 0401 /{ }^{*} 0401$
3 Statsny P. Association of the B cell alloantigen Drw4 with rheumatoid arthritis. $N$ Engl F Med 1978; 298: 869-71.

4 Ollier W, Thomson W. Population genetics of rheumatoid arthritis. Rheum Dis Clin N Am 1992; 18: 741-59.

5 Gregersen P K, Silver J, Winchester R J. The shared epitope hypothesis: an approach to understanding the molecular genetics of susceptibility to rheumatoid arthritis. Arthritis Rheum 1987; 30: 1205-13.

6 De Jongh B M, van Romunde J C J, Valkenberg H A, et al. Epidemiological study of HLA and GM in theumatoid arthritis and related symptoms in an open Dutch arthritis and related symptoms in an open

7 Thomson W, Pepper L, Payton A, et al. Absence of an association between HLA-DRB1*04 and rheumatoid arthritis in newly-diagnosed cases from the community. Ann Rheum Dis 1993; 52: 539-41.

8 Tiwari J, Terasaki P. HLA and disease associations. New York: Springer Verlag, 1985

9 Lanchbury J S, Jaeger E E, Sansom D E, et al. Strong primary selection for the Dw4 subtype of DR4 accounts for the HLA-DOW7 association with Felty's syndrome. Hum Immunol 1991; 32: 56-64.

10 Weyand C M, Hicok K C, Conn D L, Goronzy J. The influence of HLA-DR $\beta 1$ genes on disease severity in influence of HLAt-DR genes on disease severity in
rheumatoid arthritis. Ann Intern Med 1992; 117: 801-6.

11 Wordsworth P, Pile K D, Buckley J D, et al. HLA heterozygosity contributes to susceptibility to rheumatoid heterozygosity contributes to susceptibility to

12 Ollier W E R, MacGrenor A J. Genetic epidemiology of rheumatoid arthritis. Br Med Bull 1995; 51: 267-85.

13 Gough A, Faint J, Salmon M, et al. Genetic typing of patients with inflammatory arthritis at presentation can be used to predict outcome. Arthritis Rheum 1994; 37: $1166-70$.

14 Rau R, Herborn G, Sander O, et al. Absence of an impact of HLA-DRB1 alleles on disease progression of RA patient 7 years after early introduction of MTX or IM gold. Arthritis Rheum 1995; 38: S231. 
15 Nelson J L, Koepseu T, Richardson M, et al. A prospective study of HLA-DRB1 alleles and theumatoid factor as predictors of outcome of newly-diagnosed RA in women. Arthritis Rheum 1995; 38: S194.

16 Young A, Jaraquemada D, Awad J, et al. Association of HLA-DR4/DW4 and DR2/DW 2 with radiologic changes
, et al. Association of in a prospective study of patients with rheumatoid in a prospective study of patients with
arthritis. Arthritis Rheum 1984;27:20-5.

17 Symmons D P M, Barrett E M, Bankhead C R, Scott D G I, Silman A J. The incidence of rheumatoid arthritis in the United Kingdom: results from the Norfolk Arthritis Register. Br F Rheumatol 1994; 33: 735-9.

18 Bulpitt K J, Nepom G, Sharp J T, et al. X-ray erosions and Rheum 1995; 38: S331.

19 van der Heijde D M, van Riel P L, Nuver-Zwart H H, Gribnau $F$ W, van de Putte $L$ B. Effects of Gribnau F W, van hydroxychloroquine and sulphasalazine on progression of joint damage in 1036-8.

20 Dawes P T, Fowler P D, Clarke S, Fisher J, Lawton A Shadforth M F. Rheumatoid arthritis: treatment which controls C-reactive protein and erythrocyte sedimentation rate reduces radiological progression. $\mathrm{Br} \mathcal{f}$ Rheumatol 1986; 25: 44-9.

21 Pincus T, Stastny $P$, Callahan L F. Morbidity and mortality in rheumatoid arthritis according to 2,1 or 0 HLA-DR4 alleles by serotyping. Arthritis Rheum 1993; 36: S86.

22 Suret ilmor Maksymowych W. HLA-DR1, DR4 and DrB1 related subtypes in rheumatoid arthritis. Association with susceptibility but not severity in a city wide community based study. F Rheumatol 1995; 22: 2027-33.

23 Eberhardt $K$, Fex E, Johnson U, Wollheim F A. Associations of HIA-DRB and -DQB genes with 2 and 5-year outcome in rheumatoid arthritis. Ann Rheum Dis 1996; 55: 36-9.

24 Wilson J M G, Jungner G Principles and practice of screening for disease. London: HMSO, 1995. (Public Health Papers 1968; No 20, December 1995.)

25 Emery P, Salmon M, Bradley H, et al. Genetically determined factors as predictors of radiological change in patients with early symmetrical arthritis. BMF 1992; 305: 1387-9. 